\title{
p75 Neurotrophin Receptor Expression on Adult Human Oligodendrocytes: Signaling without Cell Death in Response to NGF
}

\author{
Uma Ladiwala, ${ }^{1}$ Christian Lachance, ${ }^{2}$ Steve J. J. Simoneau, ${ }^{2}$ Asha Bhakar, ${ }^{2}$ Philip A. Barker, ${ }^{2}$ and \\ Jack P. Antel ${ }^{1}$ \\ ${ }^{1}$ Neuroimmunology Unit and ${ }^{2}$ Center for Neuronal Survival, Montreal Neurological Institute, McGill University, Montreal, \\ Quebec H3A 2B4, Canada
}

\begin{abstract}
Oligodendrocytes (OLs) are the primary targets in the autoimmune disease multiple sclerosis (MS). Cell receptors belonging to the tumor necrosis factor receptor (TNF-R) superfamily, such as TNF receptors and fas, are implicated in signaling the injury response of OLs. The p75 neurotrophin receptor ( $\left.p 75^{\text {NTR }}\right)$, another member of the TNF-R superfamily, has been reported to mediate nerve growth factor (NGF)-induced apoptosis in some neural systems. To address the potential relationship between $\mathrm{p} 75^{\mathrm{NTR}}$ signaling and OL injury, we assayed adult human OLs cultured under several different conditions for p75 ${ }^{\text {NTR }}$ and tyrosine kinase receptor trkA expression, for NGFmediated apoptosis, and for NGF-mediated jun kinase (JNK) or nuclear factor (NF) $\kappa$ B activation. In the current study, we have found expression of p75 NTR on cultured adult CNS-derived human OLs but not on other glial cells. TrkA was not detected
\end{abstract}

on these OLs in any of the culture conditions tested. Treatment of the OLs with varying concentrations of NGF over a range of time periods resulted in no significant increase in numbers of terminal transferase (TdT)-mediated d-uridine triphosphate (UTP)-biotin nick-end labeling positive OLs, whereas significant cell death was observed using TNF- $\alpha$. Furthermore, unlike TNF- $\alpha$ treatment, NGF treatment did not significantly activate JNK, although both TNF- $\alpha$ and NGF induced nuclear translocation of NF- $\kappa \mathrm{B}$. These findings contrast with the recent report of NGF-mediated apoptosis in the OLs of neonatal rats matured in vitro, which express p75 ${ }^{\mathrm{NTR}}$ but not trkA (Casaccia-Bonnefil et al., 1996), and suggest that, at least in humans, p75 NTR signaling may mediate responses other than apoptosis of OLs.

Key words: p75 NTR; oligodendrocytes; human; trkA; NGF; apoptosis; multiple sclerosis; JNK; NF- $\mathrm{B}$
Oligodendrocytes (OLs) and their myelin membranes are the primary sites of tissue injury in multiple sclerosis (MS), a chronic autoimmune disease of the human adult CNS (for review, see Raine, 1990). The extent of oligodendrocyte loss varies early in the disease, but in the later progressive phase of the disease, OL loss is a constant feature (Brück et al., 1994; Raine, 1994). The precise basis for the selective injury of OLs remains to be clearly defined. Candidate cell-mediated immune effector responses include direct effector-target cell interactions or soluble factors derived from lymphocytes or glial cells.

Target cell receptors belonging to the tumor necrosis factor receptor (TNF-R) superfamily are implicated in signaling the injury response of OLs (Selmaj et al., 1991; Ozawa et al., 1994; D'Souza et al., 1995, 1996). OLs express TNF receptors in situ (Dopp et al., 1997), and TNF- $\alpha$, which is detectable within MS lesions (Selmaj et al., 1991), induces apoptosis of human adult OLs in vitro (D’Souza et al., 1995). Human OLs also express fas, both in intact brain and in culture (D’Souza et al., 1996; Bonetti and Raine, 1997), and fas ligand can be detected on glial cells, microglia, and astrocytes (D’Souza et al., 1996, 1998; Dowling et al., 1996; Bonetti and Raine, 1997) and on lymphocytes in MS lesions (D’Souza et al., 1996). Human OLs in vitro undergo cell lysis without evidence of nuclear fragmentation in response to

Received Oct. 21, 1997; revised Nov. 26, 1997; accepted Dec. 2, 1997.

This work was supported in part by the Medical Research Council of Canada and the Neuroscience Network of Centres of Excellence (Canada).

Correspondence should be addressed to Dr. Jack P. Antel, Montreal Neurological Institute, 3801 University Street, Montreal, Quebec H3A 2B4, Canada.

Copyright (C) 1998 Society for Neuroscience $0270-6474 / 98 / 181297-08 \$ 05.00 / 0$ ligation of fas with either fas ligand or with cross-linking antibody (D'Souza et al., 1996).

The precise mechanisms by which TNF and fas receptors mediate death within postmitotic OLs remain unclear, but a conserved intracellular region termed the "death domain" is required for each of these receptors to interact with the downstream signaling elements that are responsible for mediating apoptosis in other cellular systems (for review, see Baker and Reddy, 1996). The p75 neurotrophin receptor ( $\left.75^{\mathrm{NTR}}\right)$, also a member of the TNF-R superfamily, contains a death domain sequence in its cytoplasmic region, and the presence of this motif has fueled speculation that this neurotrophin receptor may play a role in mediating apoptosis in vivo (Carter and Lewin, 1997). The neurotrophins [consisting of nerve growth factor (NGF), brain-derived neurotrophic factor (BDNF), neurotrophin-3 (NT-3), and neurotrophin-4 (NT-4)] are typically considered in terms of their survival-promoting effects that are mediated by neurotrophin-dependent activation of the tyrosine kinase receptors trkA, trkB, and trkC (for review, see Barbacid, 1994). p $75^{\text {NTR }}$ was initially found to function as a coreceptor for the trk receptors (Barker and Shooter, 1994; Hantzopoulos et al., 1994; Mahadeo et al., 1994; Verdi et al., 1994), but recent data indicate that $\mathrm{p} 75^{\mathrm{NTR}}$ is also capable of autonomous signaling via neurotrophin-dependent activation of sphingomyelinase activity and nuclear factor (NF) $\kappa \mathrm{B}$ transcriptional complexes (Dobrowsky et al., 1994; Carter et al., 1996). $\mathrm{p} 75^{\mathrm{NTR}}$-mediated signaling has been implicated in the apoptosis of developing retinal cells (Frade et al., 1996) as well as in the apoptosis of neonatal rat OLs that express p $75^{\text {NTR }}$ 

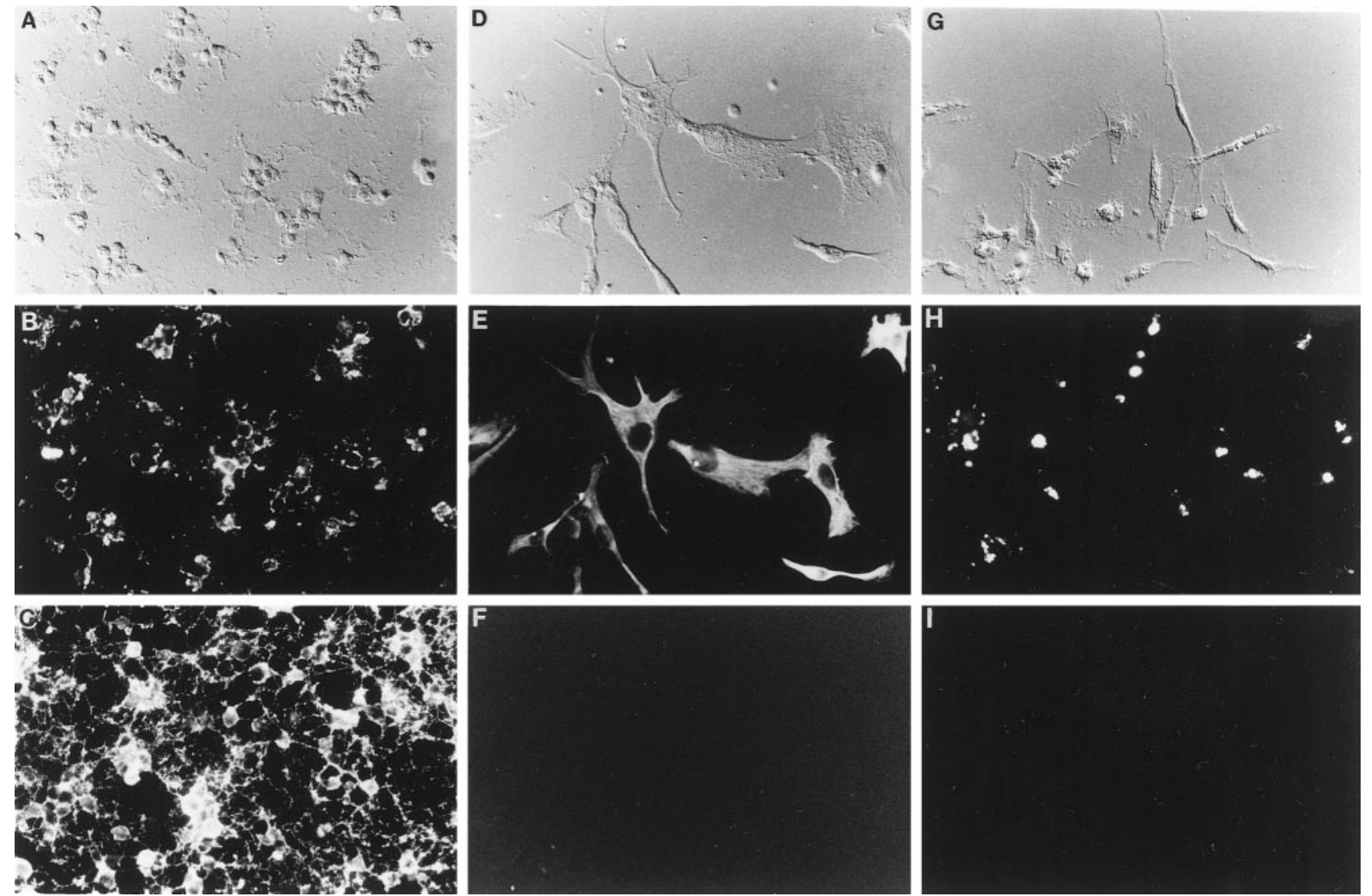

Figure 1. Expression of $\mathrm{p} 75^{\mathrm{NTR}}$ on adult human CNS-derived OLs but not on adult microglia or fetal astrocytes. $A$, Nomarski microphotograph of cultured adult OLs. B, OLs stained with $\mathrm{O} 1$ [anti-galactocerebroside (Gal C)-01] antibody. $C$, OLs stained with anti-human p75 ${ }^{\mathrm{NTR}}$ antibody. $D$, Nomarski microphotograph of cultured human fetal astrocytes. $E$, Fetal astrocytes stained with anti-GFAP antibody. $F$, Fetal astrocytes stained with anti-human $\mathrm{p} 75^{\mathrm{NTR}}$ antibody. $G$, Nomarski microphotograph of cultured adult microglia. $H$, Adult microglia stained with anti-CD68 monoclonal antibody. I, Adult microglia stained with anti-human p $75^{\mathrm{NTR}}$ antibody. All microphotographs are at a magnification of $500 \times$.

but that lack trkA(Casaccia-Bonnefil et al., 1996). An effect of p $75^{\text {NTR }}$ on OL apoptosis accompanied with increased levels of jun kinase (JNK) activity was observed on neonatal rat OLs cells that were induced to differentiate into mature OLs in vitro and maintained in minimal media, but no effect was seen on the immature precursor cells,. A separate report indicates that neonatal rodent OLs grown under more typical growth conditions express both trkA and p $75^{\text {NTR }}$ and that NGF produces a survival effect rather than apoptosis (Cohen et al., 1996).

The observations that NGF levels are elevated in the CSF of MS patients (Laudiero et al., 1992) and that MS lesions contain both apoptotic OLs (Raine and Scheinberg, 1988; Ozawa et al., 1994; Dowling et al., 1996) and immature OLs with elevated p75 ${ }^{\text {NTR }}$ expression (Dowling et al., 1997) raise the possibility that $\mathrm{p} 75^{\mathrm{NTR}}$ may play a role in the pathogenesis of MS. To address the potential relationship between $\mathrm{p} 75^{\mathrm{NTR}}$ signaling and OL injury, we cultured adult human OLs under a variety of conditions and assayed them for $\mathrm{p} 75^{\mathrm{NTR}}$ and trkA expression, for NGF-mediated apoptosis, for NGF-mediated JNK activation, and for NGF-mediated NF- $\kappa \mathrm{B}$ nuclear translocation. We have found that cultured adult human OLs express $\mathrm{p} 75^{\mathrm{NTR}}$ and not trkA, and yet, under conditions in which TNF- $\alpha$ results in readily detectable apoptosis and JNK activation, NGF treatment did not result in significant OL apoptosis or JNK activation, although it did induce nuclear translocation of NF- $\kappa \mathrm{B}$.

\section{MATERIALS AND METHODS}

Primary culture preparation. Human brain tissue was obtained from patients undergoing partial temporal lobe resection for intractable epilepsy. A total of 21 such biopsies were used for this study. The glial cell isolation procedure was as described previously (Yong and Antel, 1992). Briefly, brain tissue was subjected to enzymatic dissociation with trypsin $(0.25 \%$; GIBCO $)$ and DNase I $(25 \mu \mathrm{g} / \mathrm{ml}$; Boehringer Mannheim, Indianapolis, IN) for $30 \mathrm{~min}$ at $37^{\circ} \mathrm{C}$ and to mechanical dissociation by passage through a $132 \mu \mathrm{m}$ nylon mesh (Industrial Fabrics Corporation, Minneapolis, MN). Mixed glial cells consisting of $\sim 70 \%$ OLs, $25 \%$ microglia, and $5 \%$ astrocytes were obtained by separation on a $30 \%$ Percoll (Pharmacia, Dorval, Québec, Canada) gradient (15,000 rpm at $4^{\circ} \mathrm{C}$ for $\left.30 \mathrm{~min}\right)$. To enrich for OLs, we suspended the mixed-cell population in Eagle's minimal essential medium (MEM) supplemented with $5 \%$ fetal calf serum (FCS), $2.5 \mathrm{U} / \mathrm{ml}$ penicillin, $2.5 \mu \mathrm{g} / \mathrm{ml}$ streptomycin, 2 mM glutamine, and $0.1 \%$ glucose (all from GIBCO) and left the culture overnight in $25 \mathrm{~cm}^{2}$ uncoated Falcon tissue culture flasks (VWR Scientific Products) in a humid atmosphere at $37^{\circ} \mathrm{C}$ and $5 \% \mathrm{CO}_{2}$. The less adherent OLs were removed by gentle shaking. The remaining adherent cells in the Falcon tissue culture flasks, consisting of $\sim 95 \%$ microglia and 5\% astrocytes, were allowed to develop in MEM with 5\% FCS for $2 \mathrm{~d}$. The enriched microglial preparation was then trypsinized $(0.25 \%)$ and plated onto uncoated 9-mm-in-diameter Aclar coverslips (Seung K, University of British Columbia) or 16-well chamber slides (Nunc, Naperville, IL) for immunocytochemistry.

The OLs were plated onto poly-L-lysine- $(10 \mu \mathrm{g} / \mathrm{ml}$; Sigma, St. Louis, MO) coated 9-mm-in-diameter Aclar coverslips for immunostaining, onto 16-well tissue culture chamber slides for subsequent immunostaining and cell death assays, or onto $60 \mathrm{~mm}$ Petri dishes (VWR Scientific Products) for JNK assays and for reverse transcriptase (RT)-PCR. OLs were initially cultured in MEM with $5 \%$ FCS at a density of $5 \times 10^{4}$ cells/coverslip or 


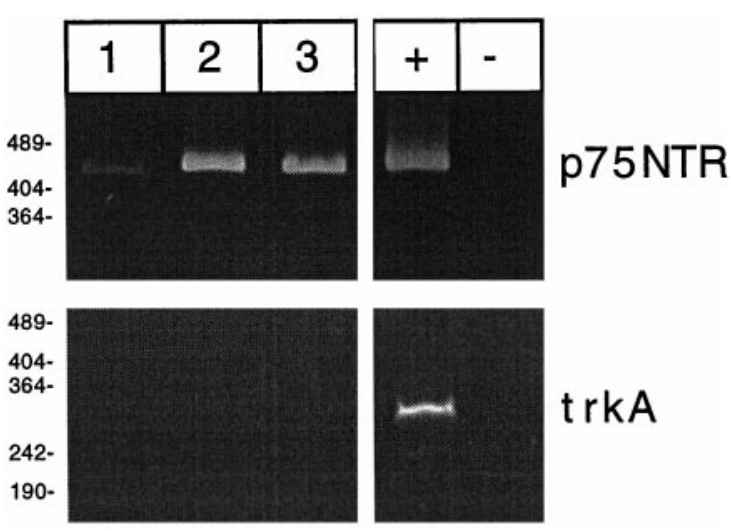

Figure 2. $775^{\mathrm{NTR}}$ mRNA, but not trkA mRNA, is expressed in adult OLs. RT-PCR was performed on RNA extracted from adult OLs grown in DMEM/F12 with PDGF-AA/b-FGF (lane 1), in serum-free MEM (lane 2), or in DMEM/F12 without PDGF-AA/b-FGF (lane 3). Control reactions were performed by substituting OL cDNA with trkA- or p $75^{\mathrm{NTR}}$-expression plasmid $(+)$ or with water $(-)$. The upper panel shows PCR results using p $75^{\mathrm{NTR}}$-specific primers, and the bottom panel shows results obtained using trkA-specific primers. DNA size markers are indicated on the left.

microwell and $1 \times 10^{6}$ cells $/ \mathrm{ml}$ in the Petri dishes for $7 \mathrm{~d}$. The cells were then washed with serum-free media and cultured under a series of conditions that would permit comparison with previous studies conducted using rodent OLs. Culture conditions used were DMEM/F12 (1:1) supplemented with $50 \mu \mathrm{g} / \mathrm{ml}$ transferrin, $20 \mathrm{nM}$ progesterone, $50 \mu \mathrm{M}$ putrescine, $30 \mathrm{~nm}$ selenium, $50 \mu \mathrm{g} / \mathrm{ml}$ insulin, $0.3 \%$ glucose, $15 \mathrm{~mm}$ HEPES, $6 \mathrm{~mm}$ glutamine, $2.5 \mathrm{U} / \mathrm{ml}$ penicillin, and $2.5 \mu \mathrm{g} / \mathrm{ml}$ streptomycin for $7 \mathrm{~d}$; DMEM/ F12 (1:1) with PDGF-AA $(20 \mathrm{ng} / \mathrm{ml})$ and b-FGF $(20 \mathrm{ng} / \mathrm{ml})$ for $4 \mathrm{~d}$ and then transferal to DMEM/F12 without PDGF-AA or b-FGF for $5 \mathrm{~d}$; and serum-free MEM (SF-MEM) for $7 \mathrm{~d}$.

For cell death and JNK assays involving NGF (Collaborative Biomedical Products), TNF- $\alpha$ (Genzyme, Boston, MA), and C2-ceramide (Molecular Probes, Eugene, OR) treatments and for NF- $\kappa \mathrm{B}$ assays using NGF (10 or $100 \mathrm{ng} / \mathrm{ml})$, TNF- $\alpha$ (1000 units/ml), and BDNF and NT-3 (100 $\mathrm{ng} / \mathrm{ml}$ each; both supplied by Regeneron Pharmaceuticals), cells were washed with serum-free media and incubated in SF-MEM or DMEM/F12 (1:1) containing $0.1 \%$ bovine serum albumin (DMEB) and supplemented with the above effector molecules as indicated in the figure legends. NGF-dependent neurite outgrowth from pheochromocytoma (PC12) cells was performed using 10 and $100 \mathrm{ng} / \mathrm{ml} \mathrm{NGF}$ to ensure that the NGF used in all experiments was bioactive (data not shown).

Because pure cultures of adult astrocytes could not be obtained, fetal human astrocytes were used as an alternative for immunocytochemical studies of p $75^{\text {NTR }}$ expression. These were prepared from human fetal CNS tissue obtained at 12-16 weeks of gestation following Medical Research of Canada guidelines. The tissues were mechanically dissociated with scalpel blades and then treated with trypsin $(0.25 \%)$ and DNase $(50 \mu \mathrm{g} / \mathrm{ml})$ at $37^{\circ} \mathrm{C}$ for $45 \mathrm{~min}$. Dissociated tissue was passed through a $130 \mu \mathrm{m}$ mesh, washed twice in PBS, and the cells, consisting of astroglia, neurons, and sparse microglia, were plated directly onto poly-L-lysine-coated $75 \mathrm{~cm}^{2}$ Falcon tissue culture flasks in MEM with 5\% FCS. After confluence, cultures were split using $0.25 \%$ trypsin. Populations of proliferating fetal astrocytes were obtained after three to four passages and plated onto uncoated $9 \mathrm{~mm}$ Aclar coverslips or 16-well chamber slides.

Immunocytochemistry. OLs were identified by staining live cells with undiluted supernatant of the O1 hybridoma (gift from Dr. W. Yong, Calgary, Canada) for $1 \mathrm{hr}$ at room temperature (RT) followed by three washes in PBS and biotinylated-goat anti-mouse IgG (1:100; Caltag, South San Francisco, CA) for $1 \mathrm{hr}$. After three rinses in PBS, cells were incubated with Cy3-conjugated Streptavidin (1:1000; Jackson ImmunoResearch, West Grove, PA) for 15 min at RT. After rinsing again with PBS, coverslips were mounted with gelvatol. The cells were also identified as mature OLs by immunostaining methanol-acetone (1:1)-fixed cells with anti-myelin basic protein (MBP) monoclonal antibody (mAb) (Boehringer Mannheim) (data not shown). Microglia were identified using anti-CD68 mAb (1:150; $1 \mathrm{hr}$ at RT; Dako, Carpenteria, CA), and permeabilized fetal astrocytes were identified using rabbit anti-glial fibrillary acidic protein (GFAP; Dako). For p75 ${ }^{\mathrm{NTR}}$ staining, anti-human p $75^{\text {NTR }}$ (Boehringer Mannheim) was used at a dilution of 1:4000 for $1 \mathrm{hr}$ at RT followed by biotinylated-goat anti-mouse $\mathrm{IgG}$ and $\mathrm{Cy}{ }^{\infty} 3$ conjugated Streptavidin. To detect nuclear translocation of NF- $\kappa \mathrm{B}$, we fixed OLs with $4 \%$ paraformaldehyde for $20 \mathrm{~min}$ at RT and followed with acetone-methanol $(1: 1)$ at $-20^{\circ} \mathrm{C}$ for $10 \mathrm{~min}$. They were then stained with a rabbit polyclonal antibody specific for the p65 subunit of NF- $\kappa \mathrm{B}$ (1:100; Santa Cruz Biotechnology, Tebu, France) for $1 \mathrm{hr}$ at RT, followed by biotinylated-goat anti-rabbit $\operatorname{IgG}(1: 100$; Caltag) for $30 \mathrm{~min}$ and Cy ${ }^{3}$-conjugated Streptavidin (1:1000) for $15 \mathrm{~min}$ at RT. For nuclear DNA staining, Hoechst 33258 (1:1000; Molecular Probes) was used on the same cells. After rinsing with PBS, coverslips were mounted with gelvatol. All slides were examined under a Reichert 2 Polyvar Leica epifluorescent microscope.

RT-PCR analysis. Total RNA was isolated from cultured OLs grown in the different culture conditions described above, using the one-step guanidinium isothiocynate procedure (Chomczinski and Sacchi, 1987). Total RNA $(2.5 \mu \mathrm{g})$ was used for first-strand cDNA synthesis using SuperScript II RNase H-reverse transcriptase (GIBCO BRL) in $20 \mu \mathrm{l}$ reactions containing $20 \mathrm{~mm}$ Tris- $\mathrm{HCl}, \mathrm{pH} 8.4,0.5 \mathrm{~mm}$ deoxynucleotides, $50 \mathrm{~mm} \mathrm{KCl}, 2.5 \mathrm{~mm} \mathrm{MgCl} 2,10 \mathrm{~mm}$ dithiothreitol, and $50 \mathrm{ng}$ of random hexamers (GIBCO BRL). Five microliters of the resulting cDNA reaction mixture were then used for nested PCR analysis. The initial PCR was performed for 35 cycles at $94^{\circ} \mathrm{C} \times 40 \mathrm{sec}, 52^{\circ} \mathrm{C} \times 60 \mathrm{sec}$, and $72^{\circ} \mathrm{C} \times$ $90 \mathrm{sec}$, and the second PCR was performed using $2.5 \mu \mathrm{l}$ of the first reaction mixture for 25 cycles at $94^{\circ} \mathrm{C} \times 40 \mathrm{sec}, 52^{\circ} \mathrm{C} \times 60 \mathrm{sec}$, and $72^{\circ} \mathrm{C} \times 90 \mathrm{sec}$. Products were analyzed on Tris-borate EDTA (TBE) acrylamide gels stained with ethidium bromide. PCR primers used for the first $\mathrm{p} 75^{\mathrm{NTR}}$ PCR were p $75^{\mathrm{NTR}}-1$ (CTC ACA CCG GGG ATG TG) and $\mathrm{p} 75^{\mathrm{NTR}}-2$ (GTG GGC CTT GTG GCC TAC), and the nested primers for the second were p75 ${ }^{\mathrm{NTR}}-3$ (TGT GGC CTA CAT AGC CTT C) and p75 ${ }^{\text {NTR }}-4$ (ATG TGG CAG TGG ACT CAC T). For trkA PCR, the initial PCR used primers trkA-1 (ATG AGA CCA GCT TCA TC) and trkA-2 (GCT GTG CTG GCG CCA GA), and the nested primers for the second were trkA-3 (AA CAA CGG CAA CTA CAC) and trkA-4 (CTT GTT TCT CCG TCC AC). The expected final product sizes from cDNA are 476 base pairs for $\mathrm{p} 75^{\mathrm{NTR}}$ and 279 base pairs for trkA; each of the primer sets span exon and intron boundaries, and genomic fragments are larger than the cDNA sizes indicated above.

Cell death assay: TUNEL staining. After exposure to putative injury mediators, cell cultures in 16-well chamber slides were washed with PBS, fixed with acetone-methanol $(1: 1)$ for $15 \mathrm{~min}$ at $-20^{\circ} \mathrm{C}$, and then rehydrated with PBS for $30 \mathrm{~min}$ at RT. Cells were then incubated with $50 \mu \mathrm{l}$ of nick end-labeling solution containing TdT (9.5 units $/ \mathrm{ml}$; Promega, Madison, WI) and biotinylated dUTP (10 nmol per ml; Boehringer Mannheim) in terminal transferase $(\mathrm{TdT}) 5 \times$ buffer $[500 \mathrm{~mm}$ cacodylate buffer, pH 6.8, $5 \mathrm{mM} \mathrm{CoCl}_{2}$, and $0.5 \mathrm{~mm}$ DTT (Promega)] for $1 \mathrm{hr}$ at $37^{\circ} \mathrm{C}$. The reaction was terminated by adding $10 \mathrm{~mm}$ Tris- $\mathrm{HCl}, \mathrm{pH} 6.8$, for $5 \mathrm{~min}$ at RT. After blocking for $5 \mathrm{~min}$ with HHG (1\% HEPES, $2 \%$ horse serum, and $10 \%$ goat serum in HBSS; all from GIBCO), the cells were incubated with Streptavidin-FITC $\left(1: 50 ; 30 \mathrm{~min}\right.$ at $37^{\circ} \mathrm{C}$; Boehringer Mannheim). To identify cell nuclei, we stained cells simultaneously with propidium iodide (PI; $10 \mu \mathrm{g} / \mathrm{ml} ; 10 \mathrm{~min}$ incubation). Slides were washed in PBS and mounted for counting. Each experiment was conducted on cells derived from at least three different brain specimens. For each experiment, all treatments were performed in replicate (three or four) wells, and 200-400 cell nuclei per well were counted using a Reichert Polyvar 2 Leica epifluorescent microscope.

$J N K$ assay. Cells grown in each of the culture conditions described above were washed in DMEM containing $0.1 \%$ BSA and then treated with putative injury mediators (NGF at $100 \mathrm{ng} / \mathrm{ml}$, TNF- $\alpha$ at $10 \mathrm{ng} / \mathrm{ml}$, and $\mathrm{C} 2$-ceramide at $25 \mu \mathrm{M}$ ) for the times indicated in the figure legends. In vitro kinase assays with whole-cell lysates were performed as described in Westwick and Brenner (1995) using Sepharose-conjugated glutathione transferase (GST)-jun (1-223) as substrate. Briefly, $15 \mu \mathrm{g}$ of cell lysate was incubated for $2 \mathrm{hr}$ at $4^{\circ} \mathrm{C}$ with the Sepharose-coupled substrate. After extensive washes, in vitro kinase assays were performed at $30^{\circ} \mathrm{C}$ for 20 min. Sepharose-associated phosphorylated substrate was resuspended in sample dissociation buffer and run on $12 \%$ SDS-PAGE. Gels were fixed and stained with Coomassie blue to confirm equal loading of GST-jun substrate and then exposed and quantitated on PhosphorImager cassettes (Storm; Molecular Dynamics, Sunnyvale, CA).

Data analysis. For TdT-mediated d-uridine triphosphate (UTP)-biotin nick-end labeling (TUNEL) assays, the total number of data points were derived as the sum of replicate wells (three or four) from at least three 
Figure 3. A, Effect of NGF on OLs in different culture conditions (DMEM/F12 with PDGF-AA/b-FGF, serumfree MEM, and DMEM/F12 without PDGF-AA/b-FGF) as measured by the TUNEL assay. Data indicate percent TUNEL-positive nuclei \pm SEM in nontreated or control cultures, in cultures with NGF at $10 \mathrm{ng} / \mathrm{ml}$ for $24 \mathrm{hr}[p>$ 0.05 , not significant (NS)], in cultures with NGF at 100 $\mathrm{ng} / \mathrm{ml}$ for $24 \mathrm{hr}(p>0.05$, NS), and in cultures with $\mathrm{C} 2$-ceramide at $50 \mu \mathrm{M}$ for $18 \mathrm{hr}(p<0.01)$ in each culture condition $(n=4)$. $B$, Percent TUNEL-positive nuclei in OLs cultured in serum-free MEM alone or exposed to either NGF at $100 \mathrm{ng} / \mathrm{ml}(p>0.05, \mathrm{NS})$ or TNF- $\alpha$ at 1000 units $/ \mathrm{ml}(p<0.01)$ for $4 \mathrm{~d}$.

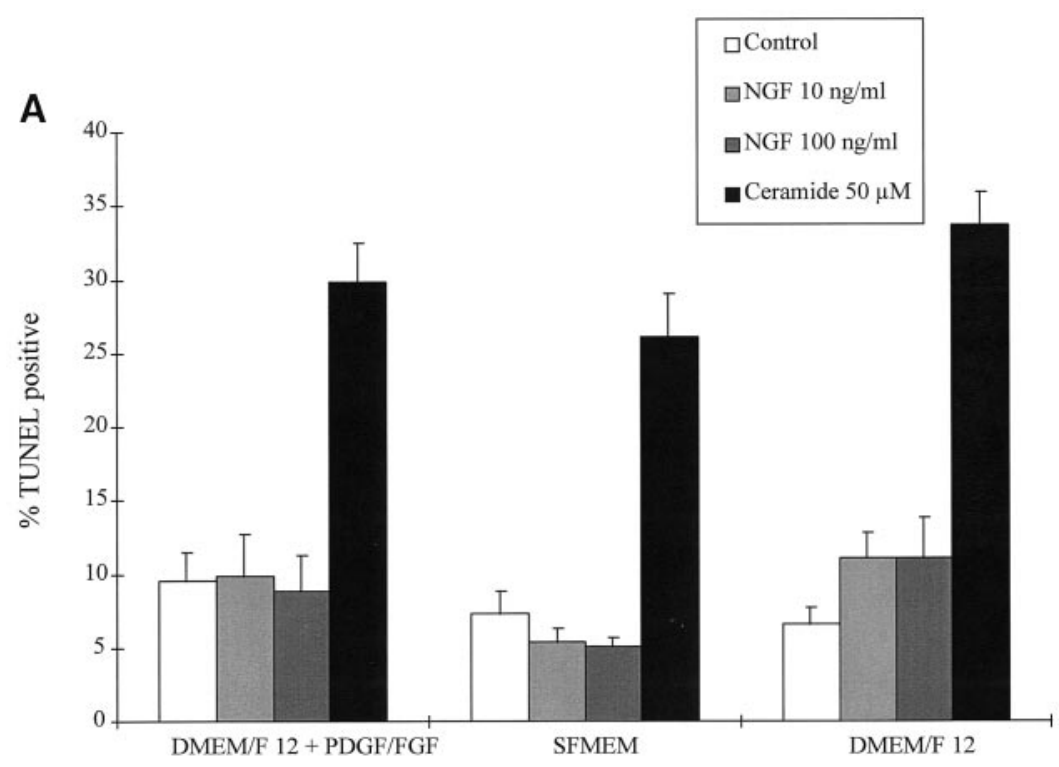

Culture conditions

B

separate experiments. Data collected from the TUNEL assays were analyzed for significance by the ordinary ANOVA test with TukeyKramer post tests if the $p$ value was $<0.05$. For the JNK assay, significance was assessed using Student's $t$ test.

\section{RESULTS}

\section{Expression of $\mathrm{p} 75^{\mathrm{NTR}}$ but not trk $\mathrm{A}$ on adult human OLs}

The morphological features of neural cells used in this study are illustrated in Figure 1, $A, D$, and $G$. Purity of the OLs in enriched cultures was estimated at $85-90 \%$ during the 2-3 week culture period. Contaminating cells included astrocytes and fibroblasts. OLs cultured in medium with b-FGF/PDGF-AA showed numerous processes. OLs grown in the different culture conditions (OLs in MEM with 5\% FCS for $7 \mathrm{~d}$ then DMEM/F12 plus PDGF-AA/ b-FGF, serum-free MEM, or DMEM/F12 only) were all O1 positive (Fig. $1 B)$. P75 ${ }^{\text {NTR }}$ expression was observed on cell bodies and

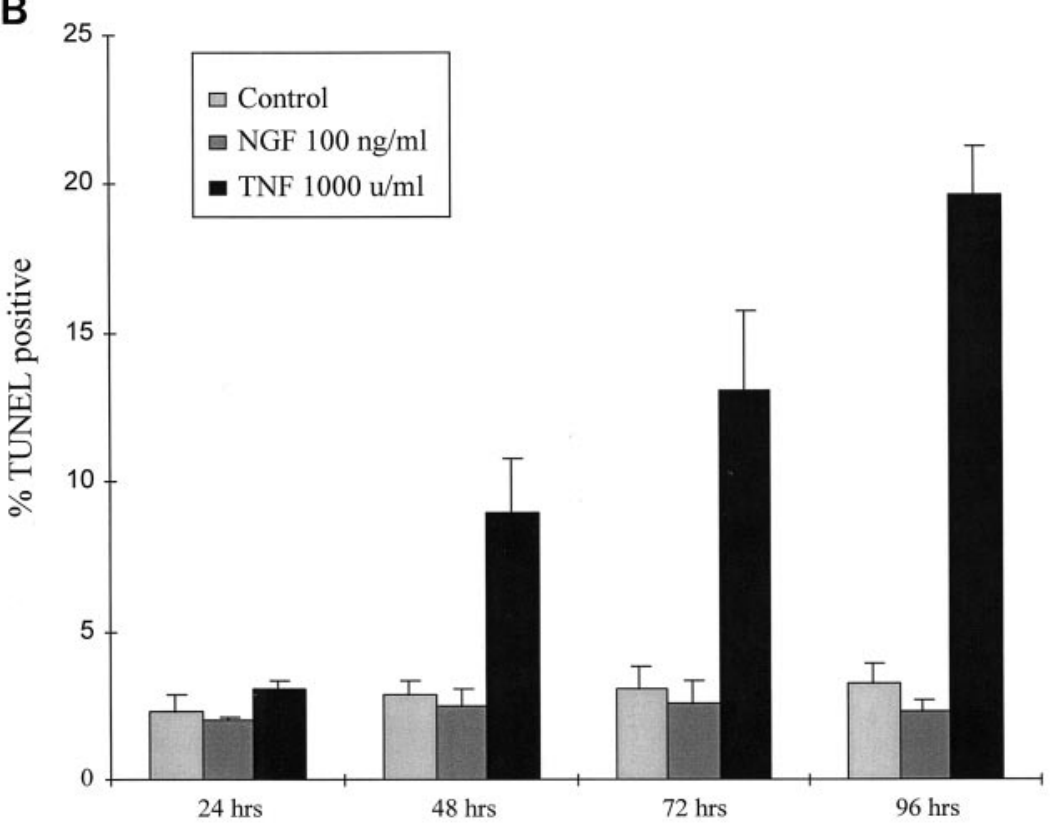

processes of OLs (Fig. 1C) under all three culture conditions. The absence of nonspecific immunoreactivity was verified by performing the immunocytochemistry protocol without primary antibody and by replacing primary antibody with isotypic control antibody. Contaminating cells with morphological characteristics of astrocytes or fibroblasts did not express $\mathrm{p} 75^{\mathrm{NTR}}$. No p $75^{\text {NTR }}$ expression could be detected on adult human microglia or fetal astrocytes in culture (Fig. 1I,F, respectively).

When the RT-PCR was performed on OL RNA using specific primers for $\mathrm{p} 75^{\mathrm{NTR}}$ and trkA, p $75^{\mathrm{NTR}}$ transcripts were detected in OLs from all three culture conditions (Fig. 2), consistent with the immunocytochemical data. Transcripts for trkA could not be detected in OLs from any of the conditions. Transcripts 2', $3^{\prime}$-cyclic nucleotide phosphodiesterase (CNPase), an OL-specific protein, were visualized (data not shown). Samples run without reverse transcriptase showed no contaminating bands. 
A

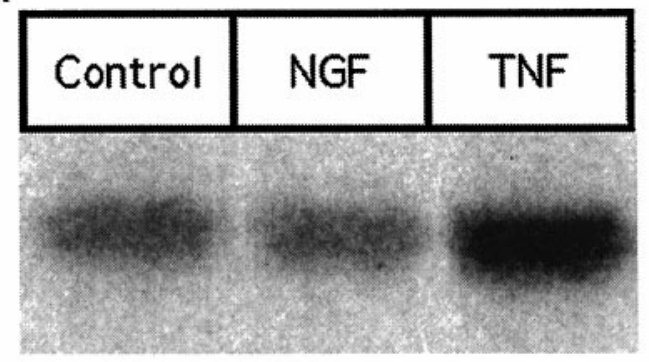

B

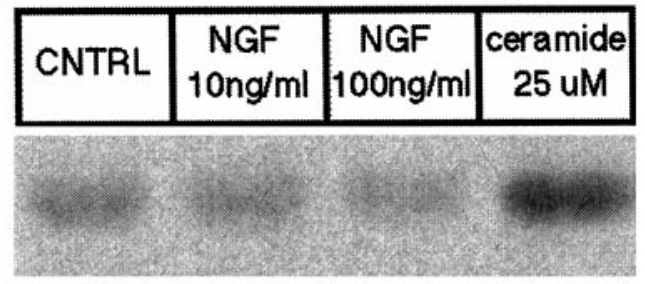

C

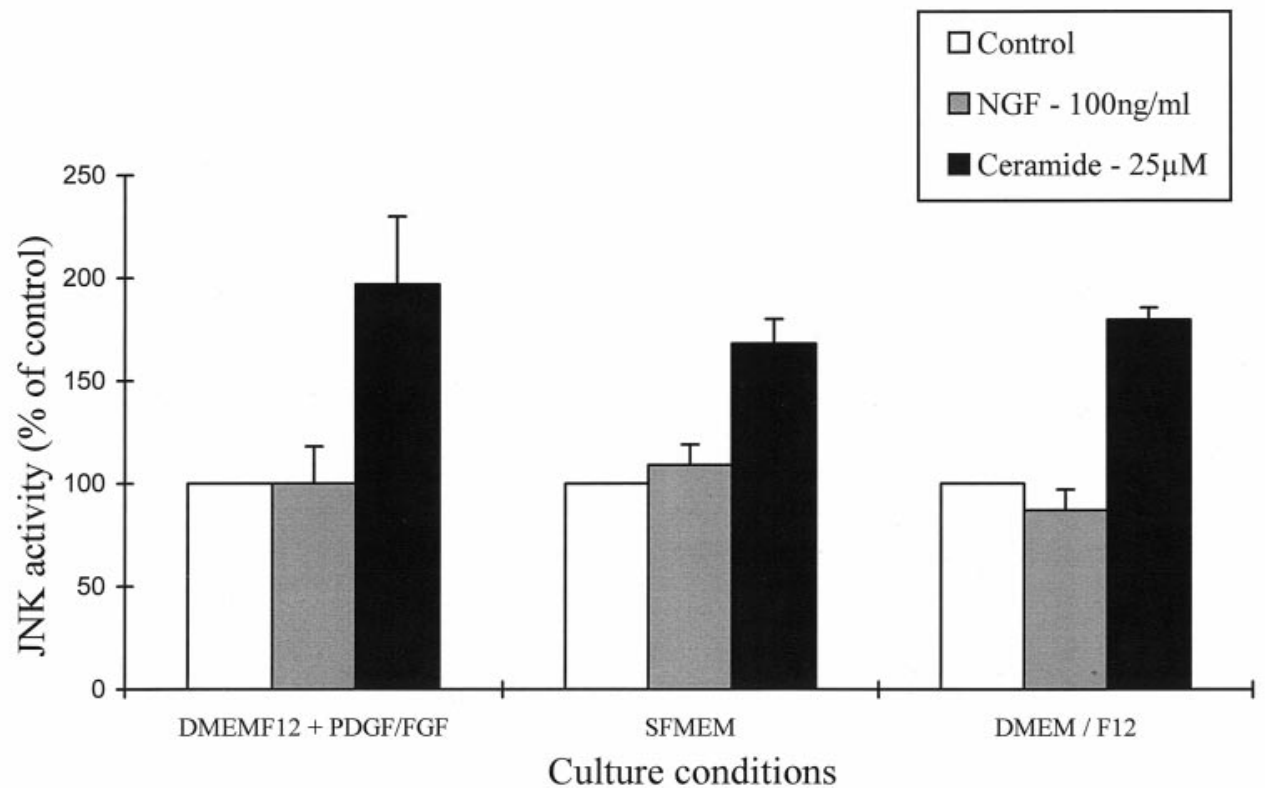

Figure 4. A, JNK activation in OLs treated with NGF or TNF- $\alpha$. Adult human OLs were cultured in serum-free MEM; data are from untreated controls (lane 1) and cultures treated for $30 \mathrm{~min}$ with NGF at $100 \mathrm{ng} / \mathrm{ml}$ (lane 2) or with TNF- $\alpha$ at $10 \mathrm{ng} / \mathrm{ml}$ (lane 3). Only TNF- $\alpha$ significantly increased JNK activity as assessed by the level of phosphorylation of GST-jun. $B$, JNK activity in OLs treated with different concentrations of NGF and with C2-ceramide. Data are from OLs in serum-free MEM untreated (lane 1) or treated with NGF at $10 \mathrm{ng} / \mathrm{ml}$ for $3 \mathrm{hr}$ (lane 2), with NGF at $100 \mathrm{ng} / \mathrm{ml}$ for $3 \mathrm{hr}$ (lane 3), or with C2-ceramide at $25 \mu \mathrm{M}$ (lane 4). Significant JNK activation was observed with C2-ceramide only. $C$, JNK activity in response to NGF treatment of OLs cultured in different conditions. Adult human OLs were cultured in DMEM/F12 with PDGF-AA/b-FGF, serum-free MEM, or DMEM/F12 without PDGF-AA/b-FGF. Cells were then treated with NGF at $100 \mathrm{ng} / \mathrm{ml}$ or C2-ceramide at $25 \mu \mathrm{M}$ for $2 \mathrm{hr}$ or left untreated (controls). JNK activity was quantified with a PhosphorImager. Values are expressed as the percent of the JNK activity of the control \pm SEM. Each bar represents the average of three different experiments. C2-ceramide induced significant JNK activation $(p<0.05)$ in each condition.

\section{NGF does not cause significant apoptosis of OLs in different culture conditions}

OLs in the different culture conditions described above were treated with 10 or $100 \mathrm{ng} / \mathrm{ml}$ of NGF for durations varying from 24 to $96 \mathrm{hr}$. TUNEL staining showed no significant apoptosis of the OLs in any of the three culture conditions with NGF at 10 $\mathrm{ng} / \mathrm{ml}$ or $100 \mathrm{ng} / \mathrm{ml}$ at $24 \mathrm{hr}$ (Fig. 3A). No increase in apoptosis was observed at any of the time points up to $96 \mathrm{hr}$. In contrast, TNF- $\alpha$ induced significant apoptosis of the OLs $(20 \pm 2 \%$; $p<$ $0.01)$ at $96 \mathrm{hr}$; Fig. 3B).

\section{NGF treatment of OLs does not lead to significant JNK activation}

JNK activity measured with a solid-phase kinase assay was not significantly increased when OLs in the different culture conditions were exposed to $100 \mathrm{ng} / \mathrm{ml} \mathrm{NGF}$ at time points up to $3 \mathrm{hr}$ (Fig. $4 A, B$ ). However, under identical conditions, both TNF- $\alpha$ $(10 \mathrm{ng} / \mathrm{ml})$ and $\mathrm{C} 2$-ceramide $(25 \mu \mathrm{M})$ were potent inducers of JNK (Fig. $4 A-C$ ).

\section{NGF induces nuclear translocation of NF- $\kappa B$}

Nuclear translocation of the $\mathrm{p} 65$ subunit of NF- $\kappa \mathrm{B}$ in response to 10 or $100 \mathrm{ng} / \mathrm{ml} \mathrm{NGF}$ was detected by immunocytochemistry in significant numbers $(26-47 \%)$ of OLs under all three culture conditions (Fig. 5C,D; Table 1) as compared with untreated (control) cultures (8-12\%) (Fig. 5A,B; Table 1) and those treated with BDNF (7-11\%) or NT-3 (7-8\%) (Table 1). This effect was observed $3 \mathrm{hr}$ after NGF treatment and was maintained for at least $6 \mathrm{hr}$. TNF- $\alpha$ induced strong nuclear staining at $30 \mathrm{~min}$ (data not shown).

\section{DISCUSSION}

In this study we show that OLs derived from human adult CNS express $\mathrm{p} 75^{\mathrm{NTR}}$ but not trkA under any of the culture conditions we have examined. In this regard, the adult human OLs differ from neonatal rat-derived OLs, because maintenance of ratderived cells in b-FGF and PDGF-AA results in expression of trkA, which likely mediates a survival response by NGF (Cohen et al., 1996). The reasons for this difference in trkA expression is 

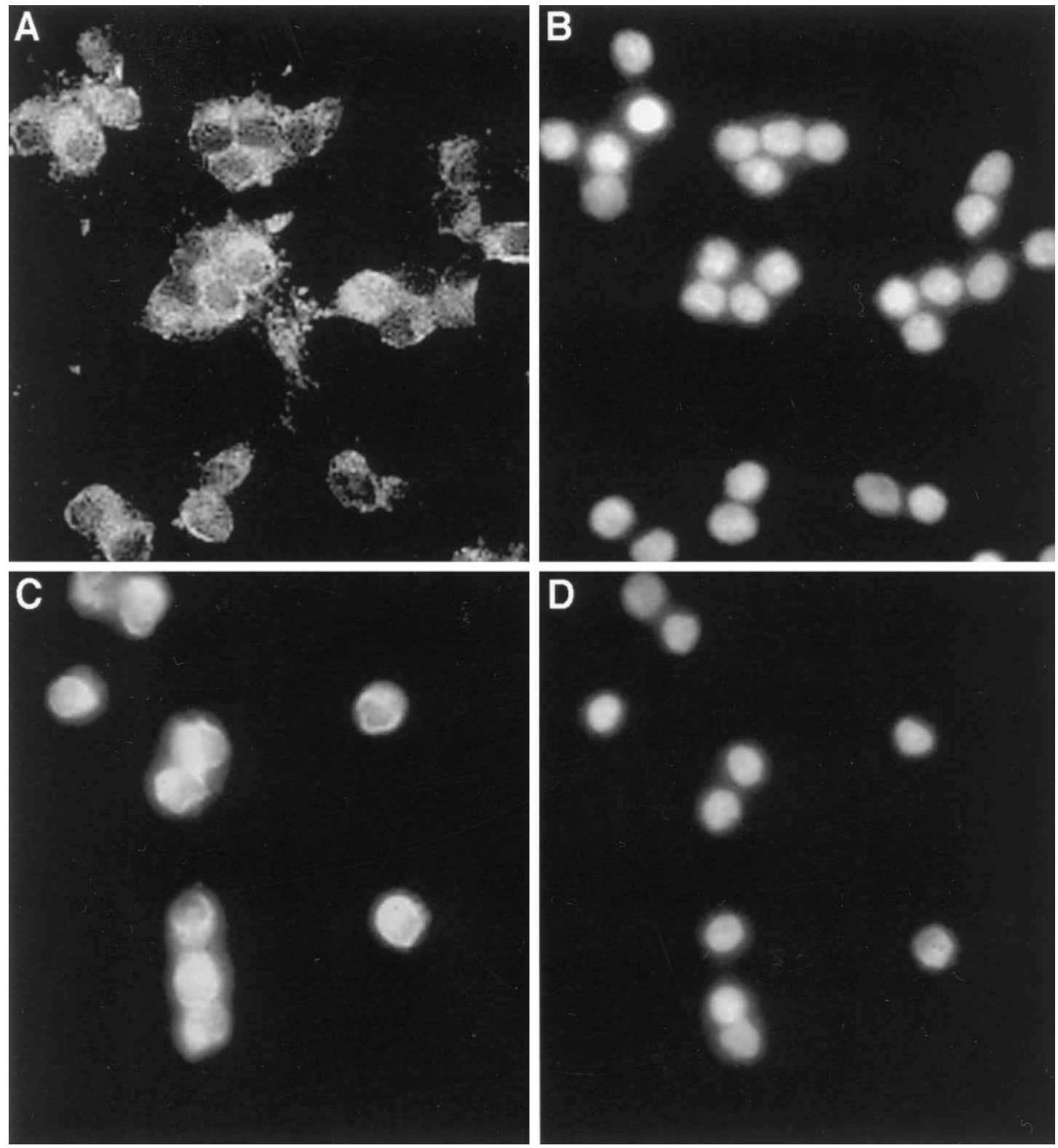

Figure 5. Nuclear translocation of NF- $\kappa \mathrm{B}$ is induced by NGF in OLs. $A$, Adult human OLs cultured in serum-free MEM; untreated controls with almost all OLs showing no nuclear staining for NF- $\kappa$ B. $B$, Nuclear DNA of OLs in the same field as in $A$ stained with Hoechst 33258 . $C$, OLs in serum-free MEM treated with $100 \mathrm{ng} / \mathrm{ml} \mathrm{NGF}$ for $3 \mathrm{hr}$ and stained with a rabbit polyclonal antibody specific for the p65 subunit of NF- $\kappa$ B. $D$, Nuclear staining of OLs in the same field as in $C$ with Hoechst 33258. All microphotographs are at a magnification of $1000 \times$.

Table 1. Nuclear translocation of NF- $\kappa$ B is induced by NGF but not by BDNF or NT-3 in OLs

\begin{tabular}{llcll}
$\begin{array}{l}\text { Culture } \\
\text { condition }\end{array}$ & $\begin{array}{l}\text { Untreated } \\
\text { controls }\end{array}$ & $\begin{array}{l}\text { BDNF } \\
(100 \mathrm{ng} / \mathrm{ml})\end{array}$ & $\begin{array}{l}\text { NT-3 } \\
(100 \mathrm{ng} / \mathrm{ml})\end{array}$ & $\begin{array}{l}\text { NGF } \\
(10 \mathrm{ng} / \mathrm{ml})\end{array}$ \\
\hline DMEM/F12 & $12 \pm 1$ & $11 \pm 2$ & $8 \pm 1$ & $42 \pm 4$ \\
DMEM/F12+PDGF/FGF & $11 \pm 2$ & $8 \pm 2$ & $7 \pm 2$ & $26 \pm 4$ \\
SF-MEM & $8 \pm 2$ & $7 \pm 3$ & $8 \pm 2$ & $26 \pm 2$
\end{tabular}

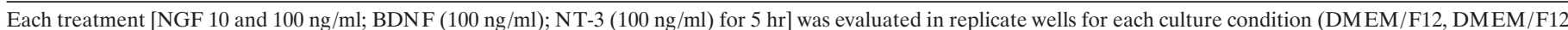

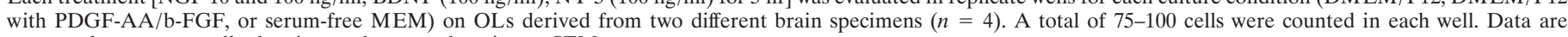
presented as percent cells showing nuclear translocation \pm SEM. 
unknown but could reflect a species-specific difference in gene expression as is seen in the expression of the CD59 receptor, a complement inhibitory protein, on human but not rodent OLs (Wing et al., 1992; Piddlesden and Morgan, 1993). It could also reflect the fact that the rat OLs used in previous studies were derived from neonatal animals, whereas the human OLs used in our studies have been postmitotic for a period of many years. In contrast, $\mathrm{p} 75^{\mathrm{NTR}}$ expression was detected in human OLs under all three culture conditions.

Our previous results have shown that TNF treatment of adult human OLs results in cellular apoptosis (D’Souza et al., 1995), indicating that a TNF-dependent apoptotic cascade is functional within these cells. In this study, we have compared the effects of TNF and NGF in our standard conditions as well as under the minimal culture conditions in which NGF treatment results in apoptosis of neonatal rat OLs. Treatment of these OLs with varying concentrations of NGF over a range of time periods resulted in no significant increase in the numbers of TUNELpositive OLs, whereas significant injury was observed using TNF.

Several previous studies have examined the expression of NGF receptors and the effects of NGF on OLs, with considerable discord between the various results. Cohen et al. (1996) have found that neonatal rat-derived OLs maintained in b-FGF and PDGF-AA express both $\mathrm{p} 75^{\mathrm{NTR}}$ and trkA, and NGF promotes the survival of these cells. NGF-mediated proliferation and process extension have been reported for porcine OLs (Althaus et al., 1992). Using minimal media to maintain neonatal rat-derived immature OLs, Casaccia-Bonnefil et al. (1996) found that rat OLs express p $75^{\text {NTR }}$ but not trkA and that these cells underwent apoptosis in response to NGF. These differing effects of NGF might be explained if activation of trkA results in a dominant proliferation or survival signal that overrides an apoptotic signal derived from $\mathrm{p} 75^{\mathrm{NTR}}$. However, our experiments show that human OLs do not express trkA under the culture conditions used either by Cohen et al. (1996) or Casaccia-Bonnefil et al. (1996) but, nonetheless, fail to undergo NGF-mediated apoptosis and $\mathrm{JNK}$ activation under conditions in which activation of JNK and apoptosis do occur in response to TNF. This difference in responsiveness in the adult human OLs suggests that the signaling properties of $\mathrm{p} 75^{\mathrm{NTR}}$ show greater cell-type and developmental variability than do those of the apoptotic TNF-R1 and Fas receptors. Reasons for this are unclear but may include differential expression of appropriate $\mathrm{p} 75^{\mathrm{NTR}}$ signaling partners that remain unidentified.

Recently, p75 ${ }^{\mathrm{NTR}}$-mediated signaling events, such as activation of NF- $\kappa$ B transcriptional complex (Carter et al., 1996) and of the sphingomyelin-ceramide pathway (Dobrowsky et al., 1994), have been identified, and both of these signaling events are consistent with a role for $\mathrm{p} 75^{\mathrm{NTR}}$ in mediating injury responses within the CNS. However, activation of NF- $\kappa \mathrm{B}$ in several cell types blocks apoptotic cell death to a variety of insults, including TNF- $\alpha$ (Beg and Baltimore, 1996; Liu et al., 1996; Van Antwerp et al., 1996). Diverse functions other than apoptosis have been attributed to autonomous $\mathrm{p} 75^{\mathrm{NTR}}$ signaling in non-neuronal cells (Herrmann et al., 1993; Anton et al., 1994). The nuclear translocation of $\mathrm{NF}-\kappa \mathrm{B}$ by NGF in human OLs may indicate a role for NF- $\kappa \mathrm{B}$ in preventing apoptosis, although its precise function remains to be determined.

Mature OLs within the CNS seem to express little, if any, p75 ${ }^{\text {NTR }}$ under normal conditions (Yan and Johnson, 1988; Heuer et al., 1990; Yamamoto et al., 1993). Substantial amounts of p $75^{\text {NTR }}$ were observed on apparently immature OLs in MS tissue
(Dowling et al., 1997). Furthermore, rats with experimental allergic encephalomyelitis, the animal model of MS, also have increased $\mathrm{p} 75^{\mathrm{NTR}}$ and NGF protein in their brains (De Simone et al., 1996). Rather than causing toxicity, NGF prevents autoimmune demyelination in marmosets (Diaz et al., 1997). $\beta$-Interferon, the approved therapy for MS, induces NGF production by astrocytes (Boutros et al., 1998). NGF and other neurotrophins continue to be considered for use as therapies in CNS neuronodegenerative disorders, emphasizing the need to define their effects on non-neuronal cells as a consequence of the therapy.

\section{REFERENCES}

Althaus HH, Kloppner S, Schmidt-Schultz T, Schwartz P (1992) Nerve growth factor induces proliferation and enhances fiber regeneration in oligodendrocytes isolated from pig adult brain. Neuroscience 135:219-223.

Anton ES, Weskamp G, Reichardt LF, Matthew WD (1994) Nerve growth factor and its low-affinity receptor promote Schwann cell proliferation. Proc Natl Acad Sci USA 91:2795-2799.

Baker SJ, Reddy EP (1996) Transducers of life and death: TNF receptor superfamily and associated proteins. Oncogene 12:1-9.

Barbacid M (1994) The trk family of neurotrophin receptors. J Neurobiol 25:1386-1403.

Barker PA, Shooter EM (1994) Disruption of NGF binding to the low affinity neurotrophin receptor $\mathrm{p} 75^{\mathrm{LNTR}}$ reduces NGF binding to trkA on PC12 cells. Neuron 13:203-215.

Beg AA, Baltimore D (1996) An essential role for NF- $\kappa \mathrm{B}$ in preventing TNF- $\alpha$-induced cell death. Science 274:782-784.

Bonetti B, Raine CS (1997) Multiple sclerosis: oligodendrocytes display cell death-related molecules in situ but do not undergo apoptosis. Ann Neurol 42:74-84.

Boutros T, Croze E, Yong VW (1997) Interferon- $\beta$ is a potent promoter of nerve growth factor production by astrocytes. J Neurochem 69:939-946.

Brück W, Schmied M, Suchanek G, Brück Y, Breitschopf H, Poser S, Piddlesden S, Lassmann H (1994) Oligodendrocytes in the early course of multiple sclerosis. Ann Neurol 35:65-73.

Carter BD, Lewin GR (1997) Neurotrophins live and let die: does p75NTR decide? Neuron 18:187-190.

Carter BD, Kaltschmidt C, Kaltschmidt B, Offenhäuser, Böhm-Matthaei $\mathrm{R}$, Baeuerle PA, Barde YA (1996) Selective activation of NF- $\kappa$ B by nerve growth factor through the neurotrophin receptor $\mathrm{p} 75$. Science 272:542-545.

Casaccia-Bonnefil P, Carter BD, Dobrowsky RT, Chao MV (1996) Death of oligodendrocytes mediated by the interaction of nerve growth factor with its receptor p75. Nature 383:716-719.

Chao MV (1994) The p75 neurotrophin receptor. J Neurobiol 25:1373-1385.

Chomczinski P, Sacchi N (1987) Single step method of RNA isolation by acid guanidium thiocyanate-phenol-chloroform extraction. Anal Biochem 162:156-159.

Cohen R, Marmur R, Norton WT, Mehler MF, Kessler JA (1996) Nerve growth factor and neurotrphin-3 differentially regulate the proliferation and survival of developing rat brain oligodendrocytes. J Neurosci 16:6433-6442.

D’Souza S, Alinauskas K, McRae E, Goodyer C, Antel JP (1995) Differential susceptibility of human CNS-derived cell populations to TNFdependent and independent immune-mediated injury. J Neurosci 15:7293-7300.

D’Souza SD, Bonetti B, Balasingam V, Cashman NR, Barker PA, Troutt AB, Raine CS, Antel JP (1996) Multiple sclerosis: fas signalling in oligodendrocyte cell death. J Exp Med 184:2361-2370.

D'Souza SD, Becher B, Troutt AB, Antel JP (1998) Fas expression on human fetal astrocytes without susceptibility to fas-mediated cytotoxicity. Neuroscience, in press.

De Simone R, Micera A, Tirassa P, Aloe L (1996) mRNA for NGF and p75 in the central nervous system of rats are affected by experimental allergic encephalomyelitis. Neuropathol Appl Neurobiol 22:54-59.

Diaz VP, Bartke I, Unger J, Fisher S, Rosenberg D, Genain CP, Hauser SL (1997) Recombinant human nerve growth factor prevents autoimmune demyelination in marmosets. Neurology 48:S15.001. 
Dobrowsky RT, Werner MH, Castellino AM, Chao MV, Hannun YA (1994) Activation of the sphingomyelin cycle through the low-affinity neurotrophin receptor. Science 265:1596-1599.

Dopp JM, Mackenziegraham A, Otero GC, Merrill JE (1997) Differential expression, cytokine modulation and specific functions of type- 1 and type-2 tumour necrosis factor receptors in rat glia. J Neuroimmunol 75:104-112.

Dowling P, Sheng G, Raval S, Menonna J, Cook S, Husar W (1996) Involvement of the CD95 (APO-1/Fas) receptor/ligand system in multiple sclerosis brain. J Exp Med 184:1513-1518.

Dowling PC, Husar W, Mennona J, Casaccia-Bonnefil P, Chao M, Cook $S$ (1997) Expression of p75 neurotrophin receptor in multiple sclerosis brain. Neurology 48:P06.083.

Frade JM, Rodriguez-Tebar A, Barde YA (1996) Induction of cell death by endogenous nerve growth factor through its p75 receptor. Nature 383:166-168.

Hantzopoulos PA, Suri C, Glass DJ, Goldfarb MP, Yancopoulos GD (1994) The low affinity NGF receptor p75 can collaborate with each of the trks to potentiate functional responses to the neurotrophins. Neuron 13:594-602.

Herrmann JL, Menter DG, Hameda J, Marchatti D, Nakajima M, Nicolson GL (1993) Mediation of nerve growth factor-stimulated extracellular matrix invasion by the human melanoma. Mol Biol Cell 4:1205-1206.

Heuer JG, Fatemie-Nainie S, Wheeler EF, Bothwell M (1990) Structure and developmental expression of the chicken NGF receptor. Dev Biol 137:287-304

Laudiero LB, Aloe L, Levi-Montalcini R, Butinelli C, Schilter D, Gillessen S, Otten U (1992) Multiple sclerosis patients express increased levels of the beta-nerve growth factor in cerebrospinal fluid. Neurosci Lett 147:9-12.

Liu Z, Hsu H, Goeddel DV, Karin M (1996) Dissection of TNF receptor 1 effector functions: JNK activation is not linked to apoptosis while NF- $\kappa$ B activation prevents cell death. Cell 87:565-576.

Mahadeo D, Kaplan L, Chao MV, Hempstead BL (1994) High affinity nerve growth factor binding displays a faster rate of association than p140trk binding. Implications for multi-subunit polypeptide receptors. J Biol Chem 269:6884-6891.

Ozawa K, Suchanek G, Breitschopf H, Brück W, Budka H, Jellinger K,
Lassmann H (1994) Patterns of oligodendroglia pathology in multiple sclerosis. Brain 117:1311-1322.

Piddlesden SJ, Morgan BP (1993) Killing of rat glial cells by complement: deficiency of the rat analogue of CD59 is the cause of oligodendrocyte susceptibility to lysis. J Neuroimmunol 48:169-176.

Raine CS (1990) Demyelinating diseases. In: Textbook of neuropathology (Davis RL, Robertson DM, eds), pp 535-620. Baltimore: Williams and Wilkins.

Raine CS (1994) The Dale McFarlin Memorial Lecture: the immunology of the multiple sclerosis lesion. Ann Neurol 36:561-572.

Raine CS, Scheinberg LC (1988) On the immunopathology of plaque development and repair in multiple sclerosis. J Neuroimmunol 20:189-201.

Selmaj KW, Raine CS, Canella B, Brosnan CF (1991) Identification of lymphotoxin and tumour necrosis factor in multiple sclerosis lesions. J Clin Invest 87:949-954.

Van Antwerp DJ, Martin SJ, Kafri T, Green DR, Verma IM (1996) Suppression of TNF- $\alpha$-induced apoptosis by NF- $\kappa$ B. Science 274:787-789.

Verdi JM, Birren SJ, Ibanez CF, Persson H, Kaplan DR, Benedetti M, Chao MV, Anderson DJ (1994) p75LNGFR regulates trk signal transduction and NGF-induced neuronal differentiation in MAH cells. Neuron 12:733-745.

Westwick JK, Brenner DA (1995) Methods for analyzing c-jun kinase. Methods Enzymol 255:342-359.

Wing MG, Zajicek J, Sceilly DJ, Compston DAS, Lachmann PJ (1992) Oligodendrocytes lack glycoprotein anchored proteins which protect them against complement lysis. Restoration of resistance to lysis by incorporation of CD59. Immunology 76:140-145.

Yamamoto M, Sobue G, Mutoh T, Li M, Doyu M, Mitsuma T, Kimata K (1993) gene expression of high- (p140trk) and low-affinity nerve growth factor receptor (LNGFR) in the adult and aged human peripheral nervous system. Neurosci Lett 158:39-43.

Yan Q, Johnson JEM (1988) An immunohistochemical study of nerve growth factor receptor in developing rats. J Neurosci 8:3481-3498.

Yong VW, Antel JP (1992) Culture of glial cells from human biopsies. In: Protocols for neural cell culture (Richardson A, Fedoroff S, eds), pp 81-86. St. Louis: Humana. 